\title{
Disaccharidase levels in the small intestine in patients with diarrhoea following vagotomy and pyloroplasty
}

\author{
J. GARCIA-PAREDES' ${ }^{1}$ AND S. C. TRUELOVE \\ From the Nuffield Department of Clinical Medicine, The Radcliffe Infirmary, Oxford
}

SUMMARY Diarrhoea is a common sequel to vagotomy and pyloroplasty but its cause is unknown. One of our patients who developed this complication had an abnormal lactose barium meal and responded well to a lactose-free diet. This led us to make a systematic study of disaccharidase activity in the small intestine in patients with diarrhoea following vagotomy and pyloroplasty.

The small-intestinal disaccharidases have been estimated in jejunal biopsy specimens taken from 23 patients suffering from persistent diarrhoea, either continuous or episodic, after vagotomy and pyloroplasty. The disaccharidase values were normal in all but one of these patients. This patient showed hypolactasia but the sucrase and maltase levels were normal. The jejunal biopsy specimen taken from this patient showed a convoluted pattern under the dissecting microscope and severe partial villous atrophy under the light microscope. A repeat jejunal biopsy taken 20 $\mathrm{cm}$ beyond the duodeno-jejunal flexure showed similar appearances and also had a low level of lactase. However, two lactose tolerance tests and a lactose barium meal yielded normal results, suggesting that the low level of lactase in the upper jejunum was not a limiting factor in lactose absorption.

The finding of one example of a low lactase level among 23 postvagotomy patients corresponds with what is being found in a study of normal subjects at present in progress.

In effect, almost all patients with persistent diarrhoea after vagotomy and pyloroplasty have normal small-intestinal disaccharidase activity.

In February 1968, a woman aged 35, the wife of a physician, was admitted as an emergency to the Nuffield Department of Clinical Medicine because of haematemesis and melaena. A barium meal showed the presence of an ulcer in the pyloric canal and she was treated surgically by vagotomy and pyloroplasty by $\mathrm{Mr}$ Milo Keynes.

After the operation she suffered from symptoms of dumping, with palpitations and faintness after meals, but these symptoms improved spontaneously until they occurred only occasionally.

In March 1969, she developed low abdominal pain and diarrhoea. The pain was colicky and preceded the diarrhoea. After two or three acts of defaecation the pain would be relieved. Physical examination was not revealing. The blood picture was normal. Barium meal and follow-through showed a wide pyloric canal and rapid gastric emptying but the stomach, duodenum, and small

Received for publication 29 September 1970.

1Present address: Department of Medicine, Hospital Clinico, Ciudad Universitaria, Madrid, Spain. intestine appeared normal. Barium enema was normal. Sigmoidoscopy showed normal appearances.

As hypolactasia was a possible cause of the diarrhoea, a jejunal biopsy was attempted but this failed because the patient retched repeatedly. As an alternative, a lactose barium meal was performed according to the method of Laws and Neale (1965). This showed appearances characteristic of hypolactasia and a repeat examination with plain barium showed normal appearances. The lactose barium meal provoked symptoms with abdominal pain, bloating, borborygmi, and diarrhoea; no such effects occurred when plain barium was used.

The patient was put on a lactose-free diet with pronounced improvement. The abdominal pain ceased and the diarrhoea became much less.

The discovery of this example of hypolactasia as a cause of postvagotomy diarrhoea led us to consider the possibility that this factor might be important in many patients suffering from the diarrhoea which is a common sequel to gastric operations involving vagotomy. Perusal of the 
relevant literature revealed no systematic studies of this possibility and we have therefore made such a study ourselves.

\section{Patients Studied}

We examined the case records of 556 patients treated by vagotomy and pyloroplasty because of duodenal ulcer (443 patients), gastric ulcer (45), combined duodenal and gastric ulcer (11), hiatus hernia (24), combined hiatus hernia and duodenal ulcer (23), and miscellaneous causes (10). Diarrhoea was a common postoperative occurrence in all these diagnostic groups, there being 119 patients $(21.4 \%)$ who experienced this symptom. The bowel habits of the patients after operation could be divided in the following way. There were 413 patients $(74.3 \%)$ in whom the bowel habits were normal; 81 patients $(14.6 \%)$ had transient diarrhoea and $38(6.8 \%)$ had persistent diarrhoea which was either continuous or episodic. Twenty-four patients $(4.3 \%)$ were constipated. Age and sex appeared to have little bearing on the liability to diarrhoea.

We interviewed a number of patients who were still suffering from troublesome diarrhoea at the time of our study and invited them to volunteer to have a small intestinal biopsy. A large proportion of them volunteered to have the examination made and it was performed successfully in 23 patients. Among these 23 patients, all but one had been treated by truncal vagotomy, the exception being case 13 who had been treated by anterior and posterior selective vagotomy.

\section{Methods}

Jejunal biopsy was performed by means of a Crosby capsule as modified by Salem, Salt, and Truelove (1965). The examination was attempted in 27 patients but in four of them the capsule failed to pass through the pylorus in spite of various manoeuvres including an injection of $10 \mathrm{mg}$ metoclopramide (Maxalon). In the remaining 23 patients a biopsy specimen was taken under fluoroscopic control from the jejunum just distal to the duodenojejunal flexure. Satisfactory biopsy specimens were obtained in all instances. The specimen was placed on a watch-glass on ice and was immediately examined under a dissecting microscope and the appearances were classified. The specimen was then divided into two parts, one portion being put into fixative for histological examination and the other being used for estimation of the disaccharidases.

The disaccharidases were estimated by the method of Burgess, Levin, Mahalanabis, and Tonge (1964) which is based on the work of Sols and De la Fuente
(1960) and Dahlqvist (1964). Results were expressed in units, one unit representing 1 micromole of disaccharide hydrolysed per minute per gram wet weight of tissue. We have taken as the lower limits of normal the following values: lactase 2.0 units, sucrase 3.0 units, and maltase 5.0 units.

\section{Results}

The Table shows the disaccharidase levels in the patients in whom jejunal biopsy was successful. In the case of lactase, only one patient (no. 9) showed hypolactasia. In the case of sucrase and maltase, all the patients were normal.

\begin{tabular}{|c|c|c|c|c|c|c|c|}
\hline \multirow{2}{*}{$\begin{array}{l}\text { Case } \\
\text { No. }\end{array}$} & \multirow[t]{2}{*}{ Initials } & \multirow[t]{2}{*}{ Sex } & \multirow[t]{2}{*}{ Age } & \multirow{2}{*}{$\begin{array}{l}\text { Years after } \\
\text { Operation }\end{array}$} & \multicolumn{3}{|c|}{ Disaccharidase (units) } \\
\hline & & & & & Lactase & Sucrase & Maltase \\
\hline 1 & N.W. & $\mathbf{F}$ & 67 & 4 & $4 \cdot 5$ & $12 \cdot 5$ & $17 \cdot 7$ \\
\hline 2 & C.H. & $\mathbf{M}$ & 44 & 6 & $2 \cdot 3$ & $8 \cdot 1$ & $4 \cdot 4$ \\
\hline 3 & T.D. & $\mathbf{M}$ & 68 & 6 & $7 \cdot 6$ & $12 \cdot 0$ & 14.0 \\
\hline 4 & T.D. & $\mathbf{M}$ & 43 & 6 & 9.0 & 12.0 & 16.8 \\
\hline 5 & T.J. & $\mathbf{M}$ & 53 & 3 & 9.9 & $17 \cdot 4$ & $17 \cdot 0$ \\
\hline 6 & K.F. & $\mathbf{M}$ & 38 & 2 & $4 \cdot 2$ & $11 \cdot 3$ & $35 \cdot 3$ \\
\hline 7 & M.P. & $\mathbf{M}$ & 47 & 4 & 4.0 & $13 \cdot 2$ & $15 \cdot 7$ \\
\hline 8 & W.C. & $\mathbf{M}$ & 39 & 6 & $2 \cdot 8$ & $4 \cdot 7$ & $17 \cdot 3$ \\
\hline 9 & L.R. & $\mathbf{M}$ & 43 & 4 & $1 \cdot 2$ & $10 \cdot 7$ & $17 \cdot 0$ \\
\hline 10 & L.S. & $\mathbf{F}$ & 80 & 6 & $5 \cdot 4$ & 11.6 & $17 \cdot 3$ \\
\hline 11 & H.B. & $\mathbf{M}$ & 38 & 2 & $2 \cdot 0$ & $9 \cdot 5$ & $18 \cdot 2$ \\
\hline 12 & F.H. & $\mathbf{M}$ & 58 & 2 & $5 \cdot 2$ & $13 \cdot 3$ & $15 \cdot 2$ \\
\hline 13 & A.W. & $\mathbf{F}$ & 58 & 3 & $8 \cdot \overline{7}$ & $6 \cdot 1$ & $19 \cdot 3$ \\
\hline 14 & W.C. & $\mathbf{M}$ & 40 & 4 & $7 \cdot 6$ & $11 \cdot 4$ & $17 \cdot 7$ \\
\hline 15 & A.D. & $\mathbf{M}$ & 60 & 3 & $4 \cdot 0$ & $11 \cdot 1$ & $16 \cdot 7$ \\
\hline 16 & H.M. & $\mathbf{M}$ & 39 & 4 & $3 \cdot 8$ & $5 \cdot 0$ & $17 \cdot 5$ \\
\hline 17 & S.B. & $\mathbf{M}$ & 37 & 4 & $3 \cdot 5$ & $5 \cdot 4$ & $18 \cdot 5$ \\
\hline 18 & W.D. & $\mathbf{M}$ & 55 & 4 & $7 \cdot 0$ & $8 \cdot 0$ & $19 \cdot 7$ \\
\hline 19 & T.A. & $\mathbf{M}$ & 51 & 4 & $4 \cdot 6$ & $7 \cdot 5$ & $20 \cdot 7$ \\
\hline 20 & A.B. & $\mathbf{M}$ & 45 & 2 & $8 \cdot 5$ & $11 \cdot 0$ & $17 \cdot 0$ \\
\hline 21 & L.R. & $\mathbf{M}$ & 48 & 6 & $4 \cdot 3$ & $10 \cdot 7$ & $17 \cdot 7$ \\
\hline 22 & J.F. & $\mathbf{M}$ & 31 & 4 & 6.9 & $8 \cdot 2$ & $18 \cdot 1$ \\
\hline 23 & S.L. & $\mathbf{M}$ & 55 & 6 & $6 \cdot 5$ & $17 \cdot 2$ & $31 \cdot 5$ \\
\hline \multicolumn{5}{|c|}{ Range } & \multicolumn{2}{|c|}{$1.2-9.95-17.4$} & $4 \cdot 4-35 \cdot 3$ \\
\hline \multirow{2}{*}{\multicolumn{5}{|c|}{$\begin{array}{l}\text { Mean } \\
\text { Standard deviation }\end{array}$}} & $5 \cdot 37$ & $10 \cdot 34$ & $18 \cdot 25$ \\
\hline & & & & & $2 \cdot 42$ & 3.41 & $5 \cdot 70$ \\
\hline \multicolumn{5}{|c|}{ Standard error of the mean } & 0.51 & 0.71 & $1 \cdot 19$ \\
\hline
\end{tabular}

Table Disaccharidase levels in jejunal biopsy specimens in patients with persistent diarrhoea after vagotomy and pyloroplasty

The dissecting microscope appearances of the jejunal specimens were normal except in two patients. In patient no. 1 the specimen showed a mixture of ridges and convolutions. In patient no. 9 (the only one with hypolactasia) there was a mixture of leaf-shaped villi, ridges, and convolutions.

The histological appearances were reported by Dr R. Whitehead as being normal in all except these same two patients. Patient no. 1 showed minor villous abnormality and patient no. 9 showed partial villous atrophy.

Patient no. 9 was further examined by a lactose tolerance test using $50 \mathrm{~g}$ lactose in $400 \mathrm{ml}$ water. 
Samples of blood were taken before and $15,30,60$, 90,120 , and 180 minutes after ingestion and the blood glucose levels were estimated by the AutoAnalyzer glucose oxidase method, based on the method of Morley, Dawson, and Marks (1968). The blood glucose level rose from $80 \mathrm{mg} / 100 \mathrm{ml}$ to a peak of $105 \mathrm{mg} / 100 \mathrm{ml} 30$ minutes after ingestion. This falls just within the normal range. There were no abdominal symptoms during or after the test.

In view of the discrepancy between the low lactase level in the jejunal biopsy specimen and the normal results of the lactose tolerance test, further observations were made in this patient.

A repeat jejunal biopsy was performed with the capsule located approximately $20 \mathrm{~cm}$ beyond the duodenojejunal flexure. This specimen also showed a convoluted pattern under the dissecting microscope and severe partial villous atrophy on histological examination, proving that the abnormal appearances of the first biopsy specimen were not simply due to chance sampling of a limited area of mucosal abnormality. Disaccharidase estimations gave these values: lactase 0.8 units (hypolactasia), sucrase 4.1 units (normal), and maltase 12.0 units (normal) and confirmed the original estimations.

A lactose barium meal was performed and showed normal appearances. A repeat lactose tolerance test with an increased dose of $100 \mathrm{~g}$ lactose gave normal values, with a peak of $85 \mathrm{mg}$ glucose above the value before the test. In spite of the normal results with the lactose tolerance tests, this patient has responded well to a lactose-free diet and has become free of symptoms.

\section{Discussion}

Any type of gastric operation for chronic peptic ulcer is liable to be followed by diarrhoea and particularly as a sequel to vagotomy and a drainage procedure.

The reason for the great frequency of postvagotomy diarrhoea is unknown, although various possibilities have been suggested. One such possibility is that the small-intestinal disaccharidases might be depressed after vagotomy. There are several studies of disaccharidase activity after gastric surgery but they deal almost entirely with patients with partial gastrectomy and include only a few isolated patients treated by vagotomy and pyloroplasty (Kojecký and Matlocha, 1965; Bank, Barbezat, and Marks, 1966; Walsh, Shaw and Walker, 1966; Drube, Hansen, Klein, and Zielke, 1967; Spencer and Welbourn, 1968; Gudman-Høyer, Jarnum, and Worning, 1969; MacDonald, Willoughby, and Weir, 1969).
The present study has demonstrated that disaccharidase deficiency is very unusual among patients with persistent episodic diarrhoea after vagotomy and pyloroplasty. Only one out of 23 patients studied showed hypolactasia and this corresponds with the incidence found in the general population; for example, in a study of normal subjects at present in progress in our department, there is one subject with definite hypolactasia out of the 19 so far studied. Moreover, the mean values and the range of lactase levels in our present group of postvagotomy subjects correspond quite closely to those quoted from several series by Levin (1969).

In effect, an occasional patient with postvagotomy diarrhoea may be found to suffer from hypolactasia and to benefit from a lactose-free diet, but the present study shows that this is an unusual situation and that the great majority of patients with postvagotomy diarrhoea have normal small-intestinal disaccharidase activity.

One of us (J.G.P.) was the holder of a British Council scholarship while this work was being carried out.

\section{References}

Bank, S., Barbezat, G. O., and Marks, I. N. (1966). Post-gastrectomy steatorrhoea due to intestinal lactase deficiency. $S$. Afr. med.J., 40, 597-599.

Burgess, E. A., Levin, B., Mahalanabis, D., and Tonge, R. E. (1964). Hereditary sucrose intolerance: levels of sucrose activity in jejunal mucosa. Arch. Dis. Childh., 39, 431-443.

Dahlquist, A. (1964). Method for assay of intestinal disaccharidases. Analyt. Biochem., 7, 18-25.

Drube, H. C., Hansen, H. T., Klein, U. E., and Zielke, K. (1967). Disaccharidase activity of the jejunal mucosa in normal subjects and patients after partial gastrectomy. Germ. med Mth., 12, 418-421.

Gudmand-Høyer, E., Jarnum, S., and Worning, H. (1969). Intestinal disaccharidase activity after Billroth II resection for peptic ulcer. Gut, 10, 451-453.

Kojecký, Z., and Matlocha, Z. (1965). Quantitative differences of intestinal disaccharidase activity following the resection of stomach. Gastroenterologia (Basel), 104, 343-351.

Laws, J. W., and Neale, G. (1966). Radiological diagnosis of disaccharidase deficiency. Lancet, 2, 139-143.

Levin, B. (1969). Disorders of carbohydrate digestion and absorption. In Disorders of Carbohydrate Metabolism. J. clin. Path., 22, Suppl. (Ass. clin. Path.), 2, 24-31.

McDonald, G. S. A., Willoughby, E., and Weir, D. G. (1969). The incidence of lactase deficiency following partial gastrectomy. Irish J. med. Sci., 8, 481-488.

Morley, G., Dawson, A., and Marks, V. (1968). Manual and autoanalyzer methods for measuring blood glucose using guaiacum, and glucose oxidase. Proc. Ass. clin. Biochem., 5, 42-45.

Salem, S. N., Salt, R. H., and Truelove, S. C. (1965). Crosby smallintestinal capsule with radio-opaque tube and latex sheath. Gut, 6, 99-100.

Sols, A., and De la. Fuente, G. (1961). Hexokinase and other enzymes of sugar metabolism in the intestine. Meth. med. Res., 9, 302-309.

Spencer, J., and Welbourn, R. B. (1968). Milk intolerance following gastric operations with special reference to lactase deficiency. Brit. J. Surg., 55, 261-264.

Walsh, J. D., Shaw, R. W. and Walker, A. (1966). Isolated lactase deficiency producing postgastrectomy milk intolerance. Ann. Intern. Med., 64, 1252-1258. 